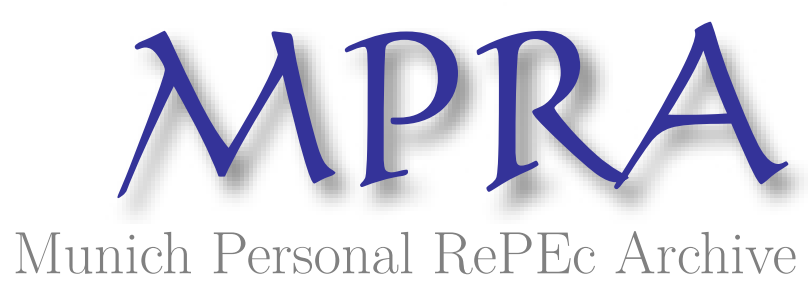

\title{
Spillover of COVID-19: Impact on the Global Economy
}

Ozili, Peterson and Arun, Thankom

2020

Online at https://mpra.ub.uni-muenchen.de/99317/

MPRA Paper No. 99317, posted 30 Mar 2020 10:56 UTC 


\title{
Spillover of COVID-19: impact on the Global Economy
}

Peterson Ozili, Central Bank of Nigeria, Nigeria

and

Thankom Arun, University of Essex, United Kingdom

\begin{abstract}
How did a health crisis translate to an economic crisis? Why did the spread of the coronavirus bring the global economy to its knees? The answer lies in two methods by which coronavirus stifled economic activities. First, the spread of the virus encouraged social distancing which led to the shutdown of financial markets, corporate offices, businesses and events. Second, the exponential rate at which the virus was spreading, and the heightened uncertainty about how bad the situation could get, led to flight to safety in consumption and investment among consumers, investors and international trade partners. We focus on the period from the start of 2020 through March when the coronavirus began spreading into other countries and markets. We draw on real-world observations in assessing the restrictive measures, monetary policy measures, fiscal policy measures and the public health measures that were adopted during the period.
\end{abstract}

JEL classification: $\mathrm{G} 21, \mathrm{G} 28, \mathrm{I11}, \mathrm{I} 18$

Keywords: Covid-19, Coronavirus, SARS-CoV-2, outbreak, pandemic, financial crisis, global recession, public health, spillovers, monetary policy, fiscal policy, liquidity provision, Central banks.

March, 2020 


\section{Introduction}

In 2019 , there was anxiety about the impact of a US-China trade war, the US presidential elections and Brexit on the World Economy. On account of these, the IMF had predicted moderated global growth of 3.4 percent. But COVID-19 - the disease caused by SARS-CoV-2, a novel strain of coronavirus from the SARS species, changed the outlook unexpectedly. Due to fear and uncertainty, and to rational assessment that firms' profits are likely to be lower due to the impact of COVID-19, global stock markets erased about US\$6 trillion in wealth in one week from 24th to 28th of February. The S\&P 500 index lost over \$5 trillion in value in the same week in the US while the S\&P 500's largest 10 companies experienced a combined loss of over $\$ 1.4$ trillion, ${ }^{1}$ although some of these were recovered in the subsequent week. Some of the loss in value was due to rational assessment by investors that firms' profits would decline due to the impact of the coronavirus.

The International Air Transportation Association (IATA) stated that the air travel industry would lose US\$113 billion if the COVID-19 outbreak was not quickly contained ${ }^{2}$. The IMF downgraded its growth projection for the global economy as the COVID-19 outbreak threw its earlier projection into serious doubt. The tourism industry was affected as the travel opportunities for Chinese tourists, who usually spend billions annually, were severely curtailed. There were increased flight cancellations, cancelled hotel bookings and cancelled local and international events worth over $\$ 200$ billion. The flow of goods through Global supply chains vastly reduced significantly given that China was the world's largest manufacturer and exporter, and the Chinese government ordered the closure of major factories. Countries like Iran, Italy and France issued stay-at-home nationwide policies to control the spread of the virus, which had already caused multiple deaths and was putting pressure on the national public healthcare infrastructure. This triggered a global recession in developed countries. There was a general consensus among economists that the coronavirus pandemic plunged the world into a global recession (Financial

\footnotetext{
${ }^{1}$ https://www.reuters.com/article/us-health-coronavirus-stocks-carnage/coronavirus-then-oil-collapse-erase-5trillion-from-u-s-stocks-idUSKBN20W2TJ

${ }^{2}$ IATA: https://airlines.iata.org/news/potential-for-revenue-losses-of-113bn-due-to-covid-19-

\%E2\%80\%9Ccrisis\%E2\%80\%9D
} 
Times, 2020). ${ }^{3}$ The International Monetary Fund in March stated that it expected a global recession that would be at least as bad as the 2007-8 global financial crisis followed by a recovery in 2021. (Georgieva, 2020) 4 .

The literature on the cause of recessions is vast (see Jagannathan et al, 2013; Stiglitz, 2010; Gaiotti, 2013; Bezemer, 2011; Mian and Sufi, 2010; Bentolila et al, 2018; Bagliano and Morana, 2012). But the cause of the 2020 global recession was novel in modern history. The coronavirus triggered a new type of recession that was different from the past triggers of recession. For instance, the Asian debt crisis of 1997 was caused by the collapse of the Thai baht in July 1997, which created panic that caused a region-wide financial crisis and economic recession in Asia (Radelet and Sachs, 1998). The 2008 global financial crisis, which translated to a recession, was caused by loose monetary policy which created a bubble, followed by subprime mortgages, weak regulatory structures, and high leverage in the banking sector (Allen and Carletti, 2010). The 2016 recession in Nigeria was caused by the fall in the price of crude oil, balance of payment deficit, adoption of a floating exchange rate regime, an increase in the pump price of petrol, activities of pipeline vandals, and infrastructure weaknesses. The 2010 recession in Greece was caused by the after-effect of the global financial crisis, structural weaknesses in the Greek economy, and lack of monetary policy flexibility as a member of the Eurozone (Rady, 2012). In this paper, we show how the coronavirus outbreak led to spillovers into major sectors of the global economy, and how fast policy response by several governments either triggered and prolonged the recession while trying to save the lives of citizens.

The discussion in this paper contributes to the financial crisis literature (Allen and Carletti, 2010; Jagannathan et al, 2013; Mian and Sufi, 2010; Stiglitz, 2010; Ozili, 2020). This paper contributes to the literature by showing that non-financial factors and/or non-economic factors can trigger both a financial and economic meltdown in unprecedented ways. The implication for financial

\footnotetext{
${ }^{3}$ Financial Times: Global recession already here, say top economists. https://www.ft.com/content/be732afe-652611 ea-a6cd-df28cc3c6a68

${ }^{4}$ Fortune: https://fortune.com/2020/03/23/coronavirus-economic-impact-predictions-great-recession-2020markets-imf/
} 
stability is that future stress testing of the resilience of the financial system should take into account human health factors as an important element in their stress testing exercises.

The rest of the paper is structured in the following way. Section 2 discusses the global spillovers. Section 3 shows the various fast policy responses adopted in several countries. Section 4 criticizes some of the policies and section 4 concludes.

\section{Spread of COVID-19 (aka coronavirus)}

Real-time data on the spread of the coronavirus (or covid-19 disease) was collected from Worldometer. The data shows that the US had the highest number of infected individuals, followed by China, Italy and Iran as at $27^{\text {th }}$ of March 2020. The statistics is reported in Table 1.

\begin{tabular}{|c|c|c|c|}
\hline \multicolumn{4}{|c|}{ Table 1: COVID-19 statistics (as at $27^{\text {th }}$ March 2020) } \\
\hline Countries & $\begin{array}{c}\text { Confirmed cases } \\
\text { (Total) }\end{array}$ & $\begin{array}{c}\text { Confirmed Deaths } \\
\text { (Total) }\end{array}$ & $\begin{array}{c}\text { Recovered } \\
\text { (Total) }\end{array}$ \\
\hline Global & 510,528 & 23,028 & 122,232 \\
\hline US & 85,612 & 1,301 & 1,868 \\
\hline Italy & 80,589 & 8,215 & 10,361 \\
\hline China & 81,340 & 3,292 & 74,588 \\
\hline Iran & 32,332 & 2,378 & 11,133 \\
\hline Spain & 57,786 & 4,365 & 7,015 \\
\hline Germany & 47,278 & 281 & 5,673 \\
\hline UK & 11,658 & 578 & 135 \\
\hline Canada & 3,579 & 36 & 185 \\
\hline France & 29,155 & 1,696 & 4,948 \\
\hline India & 719 & 16 & 45 \\
\hline South Korea & 9,332 & 139 & 4,528 \\
\hline Netherland & 7,431 & 434 & 3 \\
\hline Russia & 1,036 & 3 & 45 \\
\hline Saudi Arabia & 1,012 & 24 & 33 \\
\hline South Africa & 927 & 2 & 2 \\
\hline Nigeria & 65 & 1 & 3 \\
\hline
\end{tabular}

\footnotetext{
${ }^{5}$ https://www.worldometers.info/coronavirus/\#countries
} 
Regional data on the spread of the coronavirus (or covid-19 disease) which was reported by the World Health Organisation show that Europe had the highest number of infected cases, followed by China, Italy and Iran as at $26^{\text {th }}$ of March 2020. The statistics is reported in Table 2.

\begin{tabular}{|l|c|c|c|c|}
\hline \multicolumn{5}{|c|}{ Table 2: World Region Situation in Numbers as of 26 } \\
\hline & Confirmed cases & $\begin{array}{l}\text { New cases } \\
25 \text { March 2020 }\end{array}$ & Total Deaths & $\begin{array}{l}\text { New deaths on 25 } \\
\text { March 2020 }\end{array}$ \\
\hline Region & 413,467 & 40,712 & 18,433 & 2,202 \\
\hline $\begin{array}{l}\text { Wlobal } \\
\text { Region }\end{array}$ & 97,766 & 1,186 & 3518 & 16 \\
\hline European region & 220,516 & 25,007 & 11986 & 1797 \\
\hline South East Asia & 2,344 & 354 & 72 & 7 \\
\hline $\begin{array}{l}\text { Eastern } \\
\text { Mediterranean }\end{array}$ & 29,631 & 2,416 & 2008 & 248 \\
\hline $\begin{array}{l}\text { Region of the } \\
\text { Americas }\end{array}$ & 60,834 & 11390 & 813 & 3 \\
\hline African region & 1,664 & 359 & 29 & \\
\hline Source: World Health Organisation & & & \\
\hline
\end{tabular}

\section{Global Spillover}

Initially, the perception was that the COVID-19 pandemic would be localized in China only. It later spread across the world through the movement of people. The economic pain became severe as people were asked to stay at home, and the severity was felt in various sectors of the economy with travel bans affecting the aviation industry, sporting event cancellations affecting the sports industry, the prohibition of mass gatherings affecting the events and entertainment industries (Horowit, 2020; Elliot, 2020).

There are parallels between the COVID-19 crisis and the events of 2007: as in 2020, many people in the earlier recession assumed the impacts would largely be localized (in that case based on an assumption that the subprime mortgage crisis would be a relatively minor problem affecting only the US, but ultimately affecting the global financial system) (Elliot, 2020). The sudden economic

\footnotetext{
${ }^{6}$ https://www.who.int/docs/default-source/coronaviruse/situation-reports/20200325-sitrep-65-covid19.pdf?sfvrsn=ce13061b 2
} 
disruption caused by COVID-19 is not only destructive but also has spillover implications because it created demand and supply shocks in almost every area of human endeavor (El-Erian, 2020) ${ }^{7}$

\subsection{Spillover to the travel industry}

The coronavirus outbreak led the governments of many countries to impose restrictions on nonessential travel to countries affected by COVID-19, indefinitely suspending tourism travel, work visas and immigrant visas. Some countries placed a complete travel ban on all forms of inward or outward travel, shutting down all airports in the country. At the height of the coronavirus pandemic, most airplanes flew almost empty due to mass passenger cancellations. The travel restrictions imposed by governments subsequently led to the reduction in the demand for all forms of travel which forced some airlines to temporarily suspend operations such as Air Baltic, LOT Polish Airlines, La Compagnie, and Scandinavian Airlines. Such travel restrictions cost the tourism industry alone a loss of over $\$ 200$ billion globally, excluding other loss of revenue for tourism travel, and were forecast to cost the aviation industry a total loss of \$113billion according to IATA. ${ }^{8}$ US airlines sought a $\$ 50 \mathrm{bn}$ bailout fund for the US Airline industry alone. ${ }^{9}$ The GTBA reported that the business travel sector would lose $\$ 820$ billion in revenue due to the coronavirus pandemic. ${ }^{10}$

\subsection{Spillover to the hospitality industry}

Restaurant businesses have been affected during the pandemic mainly through the governmentannounced 'stay-at-home policy' and 'social distancing' movement restriction imposed by the government in many countries. This led to rapid shutdowns in cities and states to control the spread of the coronavirus, which threw many restaurants and hotels across the country into sudden shock. Hotels across the world witnessed booking cancellations worth billions of dollars, and the hotel industry sought a $\$ 150 \mathrm{bn}$ bailout. ${ }^{11}$ Restaurant executives laid off staff as they shut

\footnotetext{
${ }^{7}$ Foreign Affairs: https://www.foreignaffairs.com/articles/2020-03-17/coming-coronavirus-recession

${ }^{8}$ https://www.iata.org/en/pressroom/pr/2020-03-05-01/

${ }^{9}$ https://www.wsj.com/articles/airlines-seek-up-to-50-billion-in-government-aid-amid-coronavirus-crisis11584378242

${ }^{10}$ https://www.nytimes.com/reuters/2020/03/11/business/11reuters-health-coronavirus-business-travel.html

11 https://www.axios.com/hotel-industry-150-billion-coronavirus-relief-34910e41-2402-4260-b4b9-

8f5b738db664.html
} 
down their businesses temporarily as many people stayed at home, preferring to eat cooked meals at home. Some restaurant executives criticized governments for imposing the stay-athome and social distancing policy which destroyed many small restaurants and pub businesses in small cities. They argued that governments' announcements of stay-at home policies or social distancing policies was an indirect way of telling people not to come to the pubs, hotels and restaurants, which was a way of silently destroying the hospitality industry during the pandemic. ${ }^{12}$ Multiple hotels in the US, UK and in some European counties announced the temporary suspension of normal operations which puts the estimated loss of jobs to 24.3 million globally, and 3.9 million in the US alone ${ }^{13}$ due to the decline in hotel occupancy during the pandemic period. The economic impact of the pandemic on the hotel industry was more severe than the $9 / 11$ and 2008 recessions combined.

\subsection{Spillover to the sports industry}

The sports industry was severely affected during the coronavirus outbreak. In the football segment, major European football leagues in England and Scotland announced the immediate suspension of football matches for 6 weeks until $30^{\text {th }}$ April. The Turkish super league was the last major European league to suspend its matches. In Formula One, the Monaco Grand Prix was cancelled. The Tokyo Summer Olympic and Paralympic games were also postponed. In the hockey segment, the 2020 hockey games in England was postponed. England's FIH Pro League games scheduled for 2 nd to $3 \mathrm{rd}$ and 16 th to 17 th May were postponed. In rugby games, the Pro14 final scheduled for 20th June at the Cardiff City Stadium was cancelled. The major league rugby (MLR) was cancelled for the remainder of the 2020 season. In the baseball segment, all major baseball league season games were called off in Mexico and Puerto Rico. The Motorsport games in Portugal was postponed after the Portuguese government declared a state of emergency and suspended all sporting events in the country. In the snooker segment, the World snooker championship to be held in Sheffield from 18th April to 4th May, was postponed. In the swimming

\footnotetext{
${ }^{12}$ https://thebristolcable.org/2020/03/bristol-coronavirus-businesses-impact-food-restaurants-pubs-governmentthrew-us-under-bus/

${ }^{13}$ According to the American Hotel and Lodging Association. https://www.ahla.com/covid-19s-impact-hotel-industry
} 
segment, the 2020 European Aquatics Championship scheduled for $11^{\text {th }}$ to $24^{\text {th }}$ in Hungary was postponed until August. In the golf segment, the LPGA tour was rescheduled for 10th to 13th September 2020. The resulting loss in revenue to the sponsors and organizers of the cancelled games ran into billions of dollars.

\subsection{Spillover on the oil price war and the effect on oil-dependent countries}

Early in 2020, the price of oil fell due to an oil price war between Russia and Saudi Arabia. The coronavirus pandemic worsened the situation through the reduction in the demand for oil products. The imposed travel restrictions during the pandemic, which led to a reduction in the movement of people and goods, resulted in a fall in demand for aviation fuel, coal and other energy products, which subsequently led to a fall in oil price due to low demand. The coronavirus crisis also affected a wide range of energy markets such as the coal, gas and renewable energy markets, but its impact on oil markets was more severe because it stopped the movement of people and goods, which led to a drastic decline in the demand for transport fuels. When Saudi Arabia later supplied excess oil to the world, the market was flooded with too much oil, exceeding demand during the COVID-19 pandemic, and subsequently leading to a fall in oil price.

The effect of the pandemic on oil-dependent countries was severe. The global decline in oil price combined with the low demand for oil products in the international market led to a significant shortfall in oil revenue to oil-dependent countries, which increased current account deficits and worsened the balance of payment position of many oil-dependent countries such as Venezuela, Angola and Nigeria. These countries also faced increasing pressure on their foreign exchange reserves, which subsequently led to the devaluation of local currencies against the dollar. Countries like Kenya, Nigeria and South Africa experienced a reduction in the price of petrol in the local gas stations. National budgets were also affected. The sustained decline in global oil price due to the COVID-19 pandemic meant that the current national budget became outdated for most oil-dependent countries, and had to be revised because it did not reflect the current economic reality since the budget was priced at a higher oil price from 2019. Consequently, the national budget of some oil-dependent countries ran into massive deficits which forced some 
countries to either (i) seek foreign loan from the IMF to fund their budget deficits, or (ii) create a new budget that was priced using the current low oil price in the global market.

\subsection{Spillover to import-dependent countries}

Many import-dependent countries were severely affected during the coronavirus pandemic. Many countries imported their essential commodities from major exporting countries like China, India and Japan, and depend largely on these countries for the consumption of essential commodities that are imported. The reduction in goods flowing through the global supply chain, and substantial reliance on China for imported goods, led to shortages of supplies to importdependent countries as China shut down many of its export factories. This led to increases in the price of the remaining stock of imported supplies already in import-dependent country, which also triggered inflationary pressures on the price of basic commodities despite the general low demand for imports due to the coronavirus pandemic. During the coronavirus outbreak, it was difficult to seek alternative imports after China's shut-down because many countries had partially or fully closed their borders which stifled international trade at the time.

\subsection{Spillover to the financial sector: Banks and Fintech}

The macroeconomic slowdown led to a rise in nonperforming loans in the banking sector by 250 basis points. Private sector banks had the highest exposure to credit risk during the outbreak. ${ }^{14}$ Nonperforming loans arose from loans issued to small and medium scale enterprises (SMEs), airlines, hotels, tour operators, restaurants, retail, construction and real estate businesses. During the pandemic, there was a general decline in the volume of bank transactions, a decline in card payments and a fall in the use of ATM cash machines worldwide. This led to fewer fees collected by banks which negatively affected banks' profit. FinTech businesses were also affected. Some FinTech businesses witnessed very low patronage by consumers. There was a significant flight to safer investments by consumers, which negatively affected the venture capitalists that funded existing and new FinTech firms. This made many venture capitalists begin to hoard new equity which led to the drying up of financing for some FinTech businesses. On the other hand,

\footnotetext{
${ }^{14}$ https://www.ft.com/content/153f2922-6e15-11ea-89df-41bea055720b
} 
the lockdowns due to the coronavirus outbreak resulted in higher demand for some sorts of online services such as online shopping.

\subsection{Spillover to financial markets}

The most visible outcome of the COVID-19 crisis on financial markets was the effect in the global stock market. Global stock markets lost \$6 trillion in value over six days from 23 to 28 February, according to S\&P Dow Jones Indices. Between February 20 and March 19, the S\&P 500 index fell by $28 \%$ (from 3,373 to 2,409), the FTSE 250 index fell by $41.3 \%$ (from 21,866 to 12,830), and the Nikkei fell by $29 \%$ (from 23,479 to 16,552 ). In the same period, large international banks witnessed a plunge in their share price, for example, Citigroup's share price fell by $49 \%$ (from US\$78.22 to US\$39.64), JP Morgan Chase's share price fell by 38\% (from US\$137.49 to US\$85.30), and Barclays' share price fell by $52 \%$ (from $£ 181.32$ to $£ 86.45$ ). Although the oil price war, in which Russia and Saudi Arabia were driving down oil price by increasing oil production, played a role in the fall in stock markets indices, the subsequent fall in stock market indices in March was mainly due to investors' flight to safety during the coronavirus pandemic.

\subsection{Spillover to the Event industry}

Prior to 2020, the event sector contributed significantly to the economy. In 2018 , for instance, business events hosted more than 1.5 billion participants across more than 180 countries (Oxford Economics) ${ }^{15}$. The events industry generated more than $\$ 1.07$ trillion of direct spending, representing spending to plan business events, produce business events, business events-related travel, and direct spending by exhibitors. The industry also created 10.3 million direct jobs globally and generated $\$ 621.4$ billion of direct GDP. ${ }^{16}$

During the coronavirus outbreak, the events industry was hit financially by a large number of cancellations - exhibitions, live music shows, conference, weddings, parties, corporate events, brand launches, trade shows, and more. Several big events were cancelled, for instance, the E3

\footnotetext{
${ }^{15}$ https://insights.eventscouncil.org/Portals/O/OEEIC\%20Global\%20Meetings\%20Significance\%20\%28FINAL\%29\%202018-11-09-2018.pdf

${ }^{16}$ https://eventscouncil.org/coronavirus
} 
and SXSW tech events were canceled which led to direct losses beyond \$1 billion. Informa delayed or canceled events worth f400m over coronavirus pandemic. The 2020 Met Gala was postponed indefinitely. In the US, many big event management companies that were hit financially by the coronavirus outbreak appealed for federal aid from the U.S. government. The event ticketing segment of the industry was also affected. One of the biggest global ticketing and events company 'Eventbrite' announced that the COVID-19 outbreak materially affected its business outlook for 2020. The effect of the increasing cancellation on Eventbrite was so bad that the company had to withdraw its previously published 'positive outlook' for the first quarter of 2020. The effect of the outbreak on global live events was worsened by the social distancing policy imposed by several governments.

\subsection{Spillover to the entertainment industry}

The global film industry incurred a $\$ 5$ billion loss during the coronavirus outbreak. Several Hollywood movie productions were postponed indefinitely which meant goodbye to theatre and cinema. The International Alliance of Theatrical Stage Employees (IATSE) reported that an estimated 120,000 below-the-line entertainment industry jobs were lost due to the coronavirus pandemic, most of which were theatrical stage employees. The pandemic shutdown resulted in the loss of 120,000 jobs held by its 150,000 members, and the IATSE advocated that the entertainment industry should be included in the planned federal stimulus (or bailout) package. In Italy, the COVID-19 outbreak severely affected the entertainment industry which incurred losses estimated to run into the millions of euros per week: from February 23 to March 1, 2020. There were estimated losses of 7.3million euros in the film screening sector, 7.2 million euros in the theater segment, 4.1million euros in the live music segment, 2.5 million euros in the dance activities segment and 1.8 million euros in the exhibition segment. ${ }^{17}$ In the UK ${ }^{18}$, an estimated 50,000 industry freelancers were expected to lose their jobs as a result of the COVID-19 pandemic

\footnotetext{
${ }^{17}$ https://www.statista.com/statistics/1103010/impact-of-coronavirus-covid-19-on-the-entertainment-industry-initaly/

${ }^{18}$ https://www.theguardian.com/film/2020/mar/19/loss-of-jobs-income-film-industry-hollywood-coronaviruspandemic-covid-19
} 
according to BECTU (Broadcasting, Entertainment, Communications and Theatre Union). Collectively, unemployment levels in the entertainment industry rose to unprecedented highs, and yet there were doubts as to whether the entertainment industry would receive part of the planned federal stimulus package as many lawmakers argued that the entertainment industry was not a main driver of the economy, and some argue that the entertainment industry does not contribute much to economic activities compared to the banking and manufacturing sectors.

\subsection{Spillover to the health sector}

In many countries, the services of public hospitals grew in high demand but the majority of the testing equipment was in private hospitals. China temporarily closed all hospitals in the central city of Wuhan, the epicenter of a coronavirus outbreak. Iran's hospitals struggled to cope with the coronavirus outbreak. In Spain, the Spanish government nationalized all private hospitals and healthcare providers as the virus was spreading very rapidly. Singapore had sufficient healthcare facilities and workers to cope with the growing number of COVID-19 patients, ${ }^{19}$ and private hospitals were inviting and accepting foreign COVID-19 patients. The Ministry of Health (MOH) in Singapore subsequently advised all doctors in public and private hospitals, and private specialist clinics, to immediately stop accepting new foreign patients who do not live in Singapore.

The coronavirus outbreak also affected the pharmaceutical supply chain. Drug makers around the world relied heavily on ingredients made in Chinese factories. About $60 \%$ of the world's active pharmaceutical ingredients (API) were made in China before the coronavirus outbreak, and the coronavirus outbreak caused severe supply problems as China shutdown majority of its factories including factories that produce drugs. Many pharmaceutical companies did not store up substantial amounts of APIs prior to the coronavirus outbreak, and as a result, some essential drugs were in short supply. The pharmaceutical companies that had stored up a substantial amount of APIs in their warehouse refused to sell them for fear of running out of supplies while others were willing to sell only at a very high price.

\footnotetext{
${ }^{19}$ https://www.straitstimes.com/singapore/spore-has-sufficient-healthcare-facilities
} 
The overreliance on Chinese API manufacturers posed the biggest risk to the global pharmaceutical industry and the COVID-19 outbreak amplified the risk even further. Health insurers were also affected. Many health insurers in the US could not cope with the insurance payments to hospitals and the insurers sought to be included in the planned federal relief stimulus package as the health sector's economic outlook was negative. The S\&P 500 Managed Health Care index fell to 7\% in February indicating that investors felt the health care sector would be severely hit. Moody's rating agency downgraded the nonprofit and public healthcare sector's outlook from stable to negative because of the continued spread of the coronavirus disease (COVID-19). Moody's reported that the health sector was likely to see lower cash flow in 2020 compared to 2019 and falling revenue due to the cancellation of elective surgeries. The ratings agency also stated that even if the coronavirus outbreak could be contained, nonprofit healthcare companies were already facing rising expenses and widespread uncertainty. Also, investment bankers that invested heavily in health care pressured health care companies and medical supply firms to consider ways through which they can profit from the crisis by increasing prices. The effect of the outbreak on the health sector was the increase in the number of deaths due to the short supply of drugs, lack of vaccine to cure the patients, insufficient number of hospital beds and insufficient isolation centers to cater for the rising number of COVID-19 cases.

\subsection{Spillover to the education sector}

The coronavirus disrupted the $\$ 600$ billion higher education industry. ${ }^{20}$ Educators and students around the world felt the ripple effect of the coronavirus as colleges and universities were instructed to shut down after the coronavirus was declared a public health emergency in many countries. There were school closures of some kind in 44 countries on four continents, including Africa, with hundreds of millions of students around the world facing disruptions. The outbreak had a more severe consequence on schools that did not have an online learning platform. Moody's, a credit rating agency, downgraded the U.S. higher education outlook from 'stable' to 'negative', because $30 \%$ of the colleges and universities in the US already had a weak operating

\footnotetext{
${ }^{20}$ https://www.bloomberg.com/news/articles/2020-03-19/colleges-are-going-online-because-of-the-coronavirus
} 
performance, and it was difficult for these colleges and universities to adapt with the financial and academic changes required to cope with the coronavirus outbreak. Also, UNESCO reported that the COVID-19 outbreak disrupted the education of at least 290.5 million students worldwide. ${ }^{21}$ Public schools in the US were closed, Australia shut down some schools, while countries like Israel, Nigeria, Egypt, Italy, France, and Spain shut down all schools, and this created some form of unemployment for teachers. Northern Ireland's government suspended all examinations in its colleges and universities. Multiple U.S. based universities that ran a study abroad program overseas instructed students to return home from Italy, France and Spain as the coronavirus outbreak became severe in those countries. On the positive side, there were suggestions that the coronavirus outbreak increased the importance of online education and distance learning, but the reality was that only a small percentage of the world's education is taught online. For instance, in the US alone, about 2.4 million undergraduates which is equivalent to $15 \%$ of the total undergraduate students in the US studied entirely online in the fall of 2019, according to Eduventures. ${ }^{22}$ This showed that, even before the outbreak, the use of online education was already low for some reasons, and it was unlikely that the outbreak would lead to a radical shift from classroom education to online education. ${ }^{23}$ Moreover, few schools had the capacity to arrange a distance learning program for their students. Finally, countries like Canada, UK and US combined lost billions in education revenue as foreign students either quit their studies or were sent back home, while other foreign students looked elsewhere for quick education when the travel restrictions prevented them from studying in Canada, UK and US during the outbreak.

\footnotetext{
${ }^{21} \mathrm{https}$ ///en.unesco.org/themes/education-emergencies/coronavirus-school-closures

22 https://encoura.org/products-services/eduventures-research-and-advisory-services/

${ }_{23}$ The fact that numbers were low does not mean that a shift to high levels is not possible following a COVIDinspired shock. Of course, it might revert to the previous situation after campuses are reopened. But it's also possible that lecturers and students will have gained a taste of online learning, and for some it will have been found to be effective.
} 


\section{Fast Policy Response}

\subsection{General policy response}

The policy measures introduced by policy makers around the world to cope with the coronavirusinduced global recession can be divided into four categories: (i) monetary measures, (ii) fiscal measures, (iii) public health measures, and (iv) human control measures.

\begin{tabular}{|c|c|c|c|}
\hline \multicolumn{4}{|c|}{ Table 3: Some fast policy response during the 2020 global recession } \\
\hline & Type & Fast Policy Response adopted by policy makers & Countries \\
\hline \multirow[t]{5}{*}{1} & \multirow[t]{5}{*}{$\begin{array}{l}\text { Monetary policy } \\
\text { measures }\end{array}$} & $\begin{array}{l}\text { Granting regulatory forbearance to banks, and give debt } \\
\text { moratorium to debtors affected by COVID-19 }\end{array}$ & Ireland, Nigeria and Italy \\
\hline & & $\begin{array}{l}\text { Central banks' provision of liquidity to financial (bond and } \\
\text { equity) markets }\end{array}$ & China and US \\
\hline & & $\begin{array}{l}\text { Central banks purchase bonds and securities that were } \\
\text { plunging in value rapidly }\end{array}$ & Australia, EU and Canada \\
\hline & & Central banks lower interest rates & $\begin{array}{l}\text { Turkey, US, New Zealand, Japan and UK, } \\
\text { Nigeria, South Korea and Canada }\end{array}$ \\
\hline & & $\begin{array}{l}\text { Sustained flow of credit to banks, SMSEs, public health } \\
\text { sector, individuals and essential businesses }\end{array}$ & Australia, Nigeria, US and UK \\
\hline \multirow[t]{3}{*}{2} & \multirow[t]{3}{*}{ Fiscal measures } & $\begin{array}{l}\text { Governments approving a large federal stimulus package } \\
\text { for sectors and industries most affected by the COVID-19 } \\
\text { pandemic }\end{array}$ & UK, US, Australia and Nigeria \\
\hline & & Provision of income support for individuals & Australia, US, UK and India \\
\hline & & Social welfare payments to support each household & Australia, US \\
\hline \multirow[t]{4}{*}{3} & \multirow{4}{*}{$\begin{array}{l}\text { Public health } \\
\text { measure }\end{array}$} & Public quarantine & India, US, UK almost everywhere \\
\hline & & Border quarantine & $\begin{array}{l}\text { Poland, Vietnam, India, UK, US, Pakistan, } \\
\text { Australia and Colombia }\end{array}$ \\
\hline & & Issuing a stay-at-home policy & Italy, Iran, Nigeria and UK \\
\hline & & Social distancing policy & $\begin{array}{l}\text { South Africa, US, UK, UAE, Singapore, } \\
\text { Nigeria, Japan, China, India, Germany, } \\
\text { Pakistan, Australia, South Korea and Israel }\end{array}$ \\
\hline \multirow[t]{6}{*}{4} & \multirow{6}{*}{$\begin{array}{l}\text { Human control } \\
\text { measures }\end{array}$} & Temporary release of prisoners from overcrowded prisons & Iran and US \\
\hline & & Shut-down of air, land and sea borders & $\begin{array}{l}\text { Taiwan, India, Mexico, US., Germany, } \\
\text { Serbia and Nigeria }\end{array}$ \\
\hline & & Shutdown of schools & $\begin{array}{l}\text { UK, Spain, Italy, South Africa, Nigeria and } \\
\text { US }\end{array}$ \\
\hline & & $\begin{array}{l}\text { Using the military to enforce a coronavirus stay-at-home } \\
\text { lockdown }\end{array}$ & Malaysia, Italy, US and Spain \\
\hline & & Travel ban & $\begin{array}{l}\text { EU, US, Argentina, Austria, Australia, } \\
\text { Bolivia, Cambodia, Canada, China, Cape } \\
\text { Verde, Cambodia, Colombia, Croatia, } \\
\text { Denmark, Egypt, Germany, Greece and } \\
\text { Haiti }\end{array}$ \\
\hline & & Visa denial and suspension & $\begin{array}{l}\text { South Africa, Canada, Singapore, China, } \\
\text { Nigeria, Ghana, Kenya, Bolivia and Brazil }\end{array}$ \\
\hline
\end{tabular}




\subsection{Policy response by developing (CEEMEA) countries}

Some policy response (and measures) taken by Central and Eastern Europe, Middle East and Africa (CEEMEA) countries as of March 24 in 2020 are shown in table 4

\begin{tabular}{|c|c|c|c|c|c|c|c|}
\hline & $\begin{array}{l}\text { Foreign } \\
\text { travel } \\
\text { restrictions }\end{array}$ & $\begin{array}{l}\text { Internal } \\
\text { travel } \\
\text { restrictions }\end{array}$ & $\begin{array}{l}\text { State of } \\
\text { emergency } \\
\text { declared }\end{array}$ & $\begin{array}{l}\text { Limiting } \\
\text { mass } \\
\text { gathering }\end{array}$ & $\begin{array}{l}\text { Closing } \\
\text { down of } \\
\text { schools }\end{array}$ & $\begin{array}{l}\text { Restricting } \\
\text { shops \& } \\
\text { restaurants }\end{array}$ & Remarks \\
\hline Czech & $\checkmark$ & & $\checkmark$ & $\checkmark$ & $\checkmark$ & $\checkmark$ & $\begin{array}{l}\text { (i) Closure of shops \& restaurants to } \\
\text { reopen on March } 25\end{array}$ \\
\hline Hungary & $\checkmark$ & & $\checkmark$ & $\checkmark$ & $\checkmark$ & & $\begin{array}{l}\text { (i) State of emergency declared, } \\
\text { indefinitely. }\end{array}$ \\
\hline Poland & $\checkmark$ & & $\checkmark$ & $\checkmark$ & $\checkmark$ & $\checkmark$ & $\begin{array}{l}\text { (i) Shops have limited working hours, } \\
\text { (ii) restaurants and entertainment } \\
\text { venues closed until March } 28\end{array}$ \\
\hline Romania & $\checkmark$ & & $\checkmark$ & $\checkmark$ & $\checkmark$ & $\checkmark$ & $\begin{array}{l}\text { (i) Decisions announced days after } \\
\text { the new government was voted in on } \\
\text { March } 16\end{array}$ \\
\hline Russia & $\checkmark$ & & & $\checkmark$ & $\checkmark$ & & $\begin{array}{l}\text { (i) Restricted flights from and to high } \\
\text { risk areas, (ii) schools closed for } 3 \\
\text { weeks }\end{array}$ \\
\hline Ukraine & $\checkmark$ & $\checkmark$ & & $\checkmark$ & $\checkmark$ & $\checkmark$ & $\begin{array}{l}\text { (i) All air travel suspended, (ii) shop } \\
\text { and/or local transport closure varies } \\
\text { by region or city }\end{array}$ \\
\hline Egypt & $\checkmark$ & & & $\checkmark$ & $\checkmark$ & & $\begin{array}{l}\text { (i) Partial suspension of mass } \\
\text { gatherings - does not ban religious } \\
\text { gatherings, but places some } \\
\text { limitations on the size }\end{array}$ \\
\hline Israel & $\checkmark$ & $\checkmark$ & & $\checkmark$ & $\checkmark$ & $\checkmark$ & $\begin{array}{l}\text { (i) Emergency measures to be } \\
\text { enforced by the police, (ii) } 80 \% \text { of } \\
\text { employees to stay at home. }\end{array}$ \\
\hline Lebanon & $\checkmark$ & $\checkmark$ & & $\checkmark$ & $\checkmark$ & $\checkmark$ & - \\
\hline $\begin{array}{l}\text { Saudi } \\
\text { Arabia }\end{array}$ & $\checkmark$ & $\checkmark$ & & $\checkmark$ & $\checkmark$ & $\checkmark$ & - \\
\hline Turkey & $\checkmark$ & $\checkmark$ & & $\checkmark$ & $\checkmark$ & $\checkmark$ & $\begin{array}{l}\text { (i) Curfew imposed on citizens } 65 \\
\text { years old or older, (ii) around } 10,000 \\
\text { people arriving from abroad under } \\
\text { quarantine }\end{array}$ \\
\hline Ghana & $\checkmark$ & & & $\checkmark$ & $\checkmark$ & & \\
\hline Kenya & $\checkmark$ & & & $\checkmark$ & $\checkmark$ & & \\
\hline Nigeria & $\checkmark$ & & & $\checkmark$ & $\checkmark$ & & $\begin{array}{l}\text { (i) Closed all kinds of school, (ii) } \\
\text { partial shutdown of offices. }\end{array}$ \\
\hline $\begin{array}{l}\text { South } \\
\text { Africa }\end{array}$ & $\checkmark$ & & & $\checkmark$ & $\checkmark$ & $\checkmark$ & $\begin{array}{l}\text { (i) State of national disaster declared, } \\
\text { (ii) 21-day lockdown announced on } \\
\text { March } 23\end{array}$ \\
\hline India & $\checkmark$ & $\checkmark$ & & $\checkmark$ & $\checkmark$ & $\checkmark$ & $\begin{array}{l}\text { Announced a 21-day nationwide } \\
\text { lockdown }\end{array}$ \\
\hline
\end{tabular}




\subsection{Fiscal policy measures}

Fiscal policy measures were also announced in many countries to mitigate the negative economic impact of COVID-19, as shown in table 5.

\begin{tabular}{|c|c|c|c|c|c|}
\hline Countries & $\begin{array}{l}\text { Total Increase in } \\
\text { Direct Spending }\end{array}$ & $\%$ of GDP & $\begin{array}{l}\text { Fiscal Support via } \\
\text { Loans and Loan } \\
\text { Guarantees }\end{array}$ & $\%$ of GDP & Remarks \\
\hline US & USD2tn & 9.3 & USD700bn & 3.3 & Measures announced \\
\hline UK & GBP330bn & 11.8 & GBP300bn & 10.7 & Measures announced \\
\hline Canada & CAD1.1bn & & CAD10bn & & Measures announced \\
\hline Czech & CZK100bn & 1.8 & CZK900bn & 15.9 & Measures announced \\
\hline Poland & PLN70bn & 3.1 & PLN140bn & 6.2 & - \\
\hline Romania & RON9bn & 0.9 & RON12.5bn & 1.2 & - \\
\hline Russia & RUB300bn & 0.3 & - & - & Measures announced \\
\hline Egypt & EGP50bn & 0.8 & EGP50bn & 0.8 & - \\
\hline Israel & ILS2bn & 0.2 & ILS8bn & 0.5 & $\begin{array}{l}\text { An additional ILS5bn } \\
\text { under consideration }\end{array}$ \\
\hline $\begin{array}{l}\text { Saudi } \\
\text { Arabia }\end{array}$ & - & - & SAR70bn & 2,4 & - \\
\hline Turkey & - & - & TRY100bn & 2.3 & $\begin{array}{l}\text { Increased credit, } \\
\text { lower taxes and } \\
\text { deferred payments }\end{array}$ \\
\hline Nigeria & - & - & NGN3.5tn & 7.5 & $\begin{array}{l}\text { Measured } \\
\text { announced }\end{array}$ \\
\hline India & $\begin{array}{l}2.3 \text { trillion rupees } \\
\text { (unofficial) }^{24}\end{array}$ & - & - & - & $\begin{array}{l}\text { Speculated values. } \\
\text { Official figures not } \\
\text { yet announced }\end{array}$ \\
\hline
\end{tabular}

\footnotetext{
${ }^{24}$ https://www.reuters.com/article/us-health-coronavirus-india-exclusive/exclusive-india-likely-to-unveil-20billion-plus-stimulus-package-to-tackle-coronavirus-downturn-sources-idUSKBN21C1GM
} 


\subsection{Monetary policy measures}

Expansionary monetary measures were adopted by many central banks to stimulate the economy, as shown in table 6 .

\begin{tabular}{|c|c|c|c|c|c|c|}
\hline \multirow[t]{2}{*}{ Countries } & \multicolumn{3}{|c|}{ Monetary policy rate } & \multirow{2}{*}{$\begin{array}{l}\text { New asset } \\
\text { purchases }\end{array}$} & \multirow{2}{*}{$\begin{array}{l}\text { Credit and } \\
\text { liquidity } \\
\text { facilities }\end{array}$} & \multirow[t]{2}{*}{ Additional } \\
\hline & $\begin{array}{l}\text { As of } \\
\text { January } 1\end{array}$ & $\begin{array}{l}\text { Current } \\
\text { rate }\end{array}$ & $\begin{array}{l}\text { End of } 2^{\text {nd }} \\
\text { Quarter }\end{array}$ & & & \\
\hline Czech & 2.00 & 1.75 & 1.00 & $\begin{array}{l}\text { Government } \\
\text { bonds }\end{array}$ & $\begin{array}{l}\text { Increased FX } \\
\text { swap stock }\end{array}$ & - \\
\hline Hungary & 0.90 & 0.90 & 0.90 & - & - & $\begin{array}{l}\text { Grace period for loans extended to firms } \\
\text { under FGS scheme }\end{array}$ \\
\hline Poland & 1.50 & 1.00 & 0.50 & $\begin{array}{c}\text { Government } \\
\text { bonds }\end{array}$ & - & $\begin{array}{l}\text { Decreased reserve requirement and } \\
\text { increased interest rate }\end{array}$ \\
\hline Romania & 2.50 & 2.00 & 1.50 & $\begin{array}{l}\text { Government } \\
\text { bonds }\end{array}$ & - & - \\
\hline Russia & 6.25 & 6.00 & 6.00 & FX sales & - & - \\
\hline Ukraine & 13.50 & 10.00 & 8.50 & FX Sales & - & - \\
\hline Egypt & 12.25 & 9.25 & 9.25 & - & - & $\begin{array}{l}\text { Measures discussed to reduce loan } \\
\text { burden on firms and households }\end{array}$ \\
\hline Israel & 0.25 & 0.25 & 0.10 & $\begin{array}{l}\text { Government } \\
\text { bonds }\end{array}$ & & - \\
\hline Saudi Arabia & 2.25 & 1.00 & - & - & - & - \\
\hline Turkey & 12.00 & 9.75 & - & - & - & $\begin{array}{l}\text { Wide range of measures such as new } \\
\text { credit facilities, reduced reserve } \\
\text { requirements, etc. }\end{array}$ \\
\hline Ghana & 16.00 & 14.50 & 14.50 & - & - & $\begin{array}{l}\text { Reduced primary reserve requirement } \\
\text { and other ratios to release liquidity }\end{array}$ \\
\hline Kenya & 8.50 & 7.25 & - & - & - & $\begin{array}{l}\text { Reduced cash reserve ratio, extensive loan } \\
\text { restructuring }\end{array}$ \\
\hline Nigeria & 13.50 & 13.50 & - & - & - & $\begin{array}{l}\text { Measures towards moving away from } \\
\text { multiple FX regimes, reduced intervention } \\
\text { rate, reducing federal interest rate. }\end{array}$ \\
\hline India & 5.15 & 4.4 & - & & $\begin{array}{l}3.74 \text { lakh } \\
\text { crore liquidity } \\
\text { injected }\end{array}$ & $\begin{array}{l}\text { Reduced CRR to } 3 \% \text {. Three-month } \\
\text { moratorium on term loans outstanding. } \\
\text { Total liquidity injection } 3.4 \% \text { of GDP }\end{array}$ \\
\hline South Africa & 6.50 & 5.25 & 4.75 & - & - & - \\
\hline
\end{tabular}




\section{Fast policy response: Issues}

\subsection{A difficult decision}

Policy makers in government and Central banks were faced with two major decisions, which is to: 'save the people before saving the economy', or 'save the economy before saving the people'. One choice had to be made because it was difficult to achieve both at the same time. You cannot save the people and the economy at the same time because to save the people (who are also economic agents) during the outbreak you have to tell them to stay at home in order to control the spread of coronavirus which means economic activities will have to stop or reduce significantly, which will trigger an economic slowdown. Policy makers in many countries felt it was better to save the people before saving the economy, and as a result, the economy was allowed to suffer in some countries.

\subsection{Contradictory and conflicting policy response}

During the coronavirus pandemic, many of the fast policy responses were insufficient even though the policies were formulated with good intentions. Monetary policy, for instance, helped to calm financial markets but it did not stop the recession. Central banks responded to the coronavirus outbreak by changing monetary policy variables such as lowering interest rates and increasing money (or credit) supply to crucial sectors of the economy. But monetary policy alone could not induce demand when there was a general flight to safety among consumers and investors - not many people were buying anything or making new investments. It became clear to many economists that monetary policy is not a vaccine, it cannot cure a recession. The expansionary monetary policies adopted in many countries during the outbreak encouraged economic activities but economic agents were unable to engage in economic activities because governments had imposed social distancing restrictions amid fear of contacting the coronavirus during the outbreak. The central bankers were 'expecting' particular outcomes and wanted to shift the needle in that direction as much as they could, but in reality their best efforts wouldn't achieve all that much. 


\subsection{Using broad fiscal expenditure and sector priority}

Some countries used a broad federal fiscal stimulus (or bail-out) package to mitigate the economic effect of COVID-19 during the outbreak. Determining which sectors will receive part of the stimulus package and which sectors will not receive the stimulus package became a political issue in some countries like the UK and US as it stirred up debates as to whether the government considered the entertainment sector, hospitality sector and the circular economy to be less important and insignificant to the economy and ineligible to receive some funding from the federal stimulus package compared to the banking sector, manufacturing, education, pharmaceutical and the aviation sectors which were considered to be significant contributors to the economy. Some members of excluded sectors protested because they felt that the government did not consider other sectors as significant contributors to the economy.

\subsection{Fast policy destroyed some segment of the hospitality industry very fast}

Policies such as the 'stay-at-home policy' and the 'social distancing policy' severely damaged the incomes of restaurants, pub, shops and hotels in many locations, in some cases resulting in them closing down. It destroyed many businesses in the hospitality industry in ways that were not anticipated, and the government failed to take responsibility for the failure of small and large businesses that did not survive the coronavirus outbreak due to the government-imposed social distancing policy and lockdown restrictions. It was either the social distancing policy was implemented too early or the policy was taken to the extreme by citizens and travelers who were afraid to patronize such businesses for fear of contracting the COVID-19 disease. ${ }^{25}$

\footnotetext{
${ }^{25}$ It's clear that extreme isolation policies can be very effective against the coronavirus, and can give governments time to put in place tracking methods, which can be effective once the number of cases is small. It can also be the case that governments acted very robustly at a point when it looks too early damning the economic consequences of such policies.
} 


\section{Conclusion: Don't waste the coronavirus crisis}

We analysed the coronavirus outbreak and the spillover to the global economy which triggered the global recession in 2020. Policy makers in many countries were under pressure to respond to the coronavirus outbreak. As a result, many governments made fast policy decisions that had far-reaching negative effects on their respective economy - many countries plunged into a recession.

The recession which many countries experienced was a reflection of the difficult choice that policy makers had to make in choosing whether to save the economy before saving the people or to save the people before saving the economy; many countries chose the latter. There were criticisms that the policies were too fast, premature or insufficient, and that the policies contradicted one another in some areas, for instance, the accommodative monetary policy encouraged economic agents to engage in economic activities while the lockdowns and socialdistancing (stay-at-home) policy prevented economic activities from taking place.

Finally, the coronavirus-induced public health crisis created an opportunity for many governments to make lasting reforms in the public health sector. Countries like the UK and Spain repaired their public health care system, and fixed other shortcomings in public infrastructure such as the transition to online education, transportation systems and the disease detection systems in public hospitals. Some governments also used the crisis as an opportunity to fix the economic system and the financial system with the planned federal stimulus package. 


\section{Reference}

Allen, F., \& Carletti, E. (2010). An overview of the crisis: Causes, consequences, and solutions. International Review of Finance, 10(1), 1-26.

Bagliano, F. C., \& Morana, C. (2012). The Great Recession: US dynamics and spillovers to the world economy. Journal of Banking \& Finance, 36(1), 1-13.

Bentolila, S., Jansen, M., \& Jiménez, G. (2018). When credit dries up: Job losses in the great recession. Journal of the European Economic Association, 16(3), 650-695.

Bezemer, D. J. (2011). The credit crisis and recession as a paradigm test. Journal of Economic Issues, 45(1), 1-18.

El-Erian, M. (2020). The Coming Coronavirus Recession and the Uncharted Territory Beyond. Foreign Affairs, Media Report. Available at: https://www.foreignaffairs.com/articles/2020-0317/coming-coronavirus-recession

Financial Times (2020). Global recession already here, say top economists. Available at: https://www.ft.com/content/be732afe-6526-11ea-a6cd-df28cc3c6a68

Gaiotti, E. (2013). Credit availability and investment: Lessons from the "great recession". European Economic Review, 59, 212-227.

Georgieva, K (2020). IMF Managing Director Kristalina Georgieva's Statement Following a G20 Ministerial Call on the Coronavirus Emergency. IMF Press statement. Available at: https://www.imf.org/en/News/Articles/2020/03/23/pr2098-imf-managing-director-statementfollowing-a-g20-ministerial-call-on-the-coronavirus-emergency

Horowit, J. (2020). The global coronavirus recession is beginning. CNN. Media report. Available at: https://edition.cnn.com/2020/03/16/economy/global-recession-coronavirus/index.html

Jagannathan, R., Kapoor, M., \& Schaumburg, E. (2013). Causes of the great recession of 20072009: The financial crisis was the symptom not the disease. Journal of Financial Intermediation, 22(1), 4-29. 
Larry Elliot, L. (2020). Prepare for the coronavirus global recession. The Guardian. Media report. Available at: https://www.theguardian.com/business/2020/mar/15/prepare-for-thecoronavirus-global-recession

Mian, A., \& Sufi, A. (2010). The great recession: Lessons from microeconomic data. American Economic Review, 100(2), 51-56.

Ozili, P. K. (2019). 100 Quotes from the Global Financial Crisis: Lessons for the future. Available at SSRN 3500921.

Radelet, S., \& Sachs, J. (1998). The onset of the East Asian financial crisis (No. w6680). National bureau of economic research.

Rady, D. A. M. (2012). Greece debt crisis: Causes, implications and policy options. Academy of Accounting and Financial Studies Journal, 16, 87.

Stiglitz, J. E. (2010). Interpreting the Causes of the Great Recession of 2008. Financial system and macroeconomic resilience: revisited. Bank for International Settlements. 